ŠOLJIĆ, A., Elektronički dokazi u parničnom postupku Bosne i Hercegovine Zbornik radova Pravnog fakulteta Sveučilišta u Mostaru, br. XXVII., 2019., str. 121. - 137.

Andrea ŠOLJÍ, mag.iur

Općinski sud Livno

pericandrea11@gmail.com
UDK: 347.958 (497.6)

Pregledni znanstveni rad Primljen: 28. kolovoza 2018.

Prihvaćen: 24. svibnja 2019.

\title{
ELEKTRONIČKI DOKAZI U PARNIČNOM POSTUPKU BOSNE I HERCEGOVINE
}

\begin{abstract}
Sažetak: Dokazivanje je središnji dio parničnog postupka kojemu je cilj utvrdivanje činjenica koje su bitne za donošenje odluke. Taj postupak se odvija na način propisan zakonom. Po parničnom zakonodavstvu Bosne i Hercegovine inicijativa $z a$ predlaganje dokaza je u rukama stranaka. Sud je samo iznimno ovlašten po službenoj dužnosti utvrdivati činjenice koje stranke nisu iznijele i izvoditi dokaze koje stranke nisu predložile. Bez obzira na dokazna sredstva koja su predvidena u zakonu, pravno relevantne činjenice mogu se utvrđivati svim mogućim sredstvima obavještavanja koja su pribavljena na zakonit način. U ovome radu autorica će iznijeti opće odredbe o dokazivanju, dok će drugi dio rada biti posvećen elektroničkim dokazima.
\end{abstract}

Razvoj tehnologije ima utjecaj na sve sfere društva, pa tako i na sudski postupak. Komunikacija i poslovanje se sve više vrši elektroničkim putem. Na taj način dolazi do pohranjivanja raznih podataka koji mogu poslužiti kao dokaz u sudskom postupku. U radu se objašnjava što su to elektronički dokazi te njihovo korištenje u građanskom sudskom postupku Bosne i Hercegovine. Iako suci imaju slobodu prilikom odlučivanja te nisu vezani zakonskim pravilima u pogledu ocjene dokaza, kod odredenih elektroničkih dokaza postoje zakonske presumpcije koje utječu na pravnu vrijednost takvih dokumenata.

Ključne riječi: dokazivanje, elektronički dokazi, elektronički dokument, vještačenje, informatizacija

\section{Uvod}

Informacijska je tehnologija promijenila način funkcioniranja u društvu. Ljudi lakše i brže komuniciraju i brže zaključuju pravne poslove. Na taj način dolazi do pojave elektroničkih dokaza. Pravni sustav je po svojoj prirodi spor i uvijek mu je potrebno više vremena da se prilagodi društvenim promjenama. 
Kako u pogledu elektroničkih dokaza nema posebnih pravila vezanih za njihovo izvođenje i ocjenjivanje primjenjuju se pravila o dokazivanju propisana zakonom o parničnom postupku. ${ }^{1}$ Zakonodavac nije propisao kojim se dokazima dokazuju pojedine činjenice. ${ }^{2}$ Ocjena dokaza je prepuštena slobodnoj ocjeni suda. Kada govorimo o slobodnoj ocjeni suda ona nije arbitrarna, ona se mora temeljiti na pravilima logike i životnog iskustva. Dokazni se postupak sastoji od niza radnji suda i stranaka. Te radnje obuhvaćaju prijedloge stranaka za izvođenjem dokaza, odluku suda koji će se od predloženih dokaza izvesti te naposljetku izvođenje dokaza. Nakon što se provedu navedene radnje sud pristupa ocjeni dokaza i donošenju odluke. Kod elektroničkih dokaza važno je dokazati njihovu autentičnost. S obzirom na stranačku inicijativu kod predlaganja dokaza, stranke su dužne dokazati i autentičnost elektroničkih dokaza koje su predložile.

Kako sud na prijedlog stranke određuje izvođenje dokaza vještačenjem kada je radi utvrđenja ili razjašnjenja određene činjenice potrebno stručno znanje kojim sud ne raspolaže, autentičnost elektroničkih dokaza najčešće će se utvrđivati vještačenjem. Prilikom ocjene takvih dokaza sud treba nakon donošenja odluke o autentičnosti dokaza ocijeniti i sadržaj takvog dokaza.

Sukladno direktivama Europske unije ${ }^{3}$ Bosna i Hercegovina (BiH) mora stvoriti pretpostavke za elektronski pristup informacijama. U skladu s tim na području $\mathrm{BiH}$ doneseni su zakoni o elektroničkom potpisu i elektroničkom dokumentu kojima je propisana pravna snaga elektroničkog dokumenta i koji uvjeti trebaju

U ovome će radu biti navedene odredbe Zakona o parničnom postupku Federacije BiH (Službene novine Federacije BIH, broj: 53/03, 73/05, 19/06 i 98/15, dalje u tekstu ZPP F $\mathrm{BiH}$ ), s obzirom da su Zakon o parničnom postupku Republike Srpske (Službeni glasnik $R S$ br. 58/03, 85/03, 74/05, 63/07, 49/09 i 61/13), te Zakona o parničnom postupku Distrikta Brčko BiH (Službeni glasnik $D B$ br. 28/18) na jednak način regulirali navedenu materiju.

2 Postoje činjenice koje se mogu dokazati samo određenim dokaznim sredstvima: sporazum o mjesnoj nadležnosti se može dokazati samo ispravom koja ga sadrži (čl. $52 \mathrm{ZPP}-\mathrm{a}$ F BiH), punomoć se može dokazati samo na načine koji su propisani zakonom (čl. 308 ZPP-a F BiH), itd. Opširnije u Dika, M., „O nedopuštenim dokazima u parničnom postupku“, Zbornik Pravnog fakulteta Sveučilišta u Rijeci, v. 37, br. 1, 2016., 3. - 32.

23. srpnja 2014. godine usvojena je Uredba br. 910/2014 Europskog parlamenta i Vijeća o elektroničkoj identifikaciji i uslugama povjerenja za elektroničke transakcije na unutarnjem tržištu i stavljanju izvan snage Direktive 1999/93/EZ kojom se utvrđuju uvjeti pod kojima države članice priznaju sredstva elektroničke identifikacije fizičkih i pravnih osoba koja su obuhvaćena prijavljenim sustavom elektroničke identifikacije druge države članice; utvrđuju pravila za usluge povjerenja posebno za elektroničke transakcije i uspostavlja pravni okvir za elektroničke potpise, elektroničke pečate, elektroničke vremenske žigove, elektroničke dokumente, usluge elektroničke preporučene dostave i usluge certificiranja za autentifikaciju mrežnih stanica. 
biti ispunjeni da bi elektronički dokument imao istu pravnu valjanost kao i dokument na papiru, te pravno djelovanje elektroničkog potpisa. Zakonom su definirane i karakteristike koje elektronički dokument mora sadržavati da bi imao pravnu presumpciju vjerodostojnosti i cjelovitosti.

\section{Dokazivanje}

Dokazivanje predstavlja središnji i najvažniji dio parničnog postupka. Cilj dokaznog postupka je utvrđivanje činjeničnog stanja na koje će sud primijeniti odgovarajuću pravnu normu te donijeti odluku o sporu među strankama. Dokazivanje je niz parničnih radnji procesnih subjekata koje se sastoje u predlaganju, izboru, prikupljanju, ispitivanju i ocjenjivanju dokaznih sredstava radi utvrđivanja istinitosti tvrdnja parničnih stranaka i pretpostavaka suda o činjenicama koje su bitne za primjenu prava. ${ }^{4}$

Postupak dokazivanja provodi se kroz nekoliko faza. Prva od njih je predlaganje dokaza. Po ZPP-u F BiH „stranke su dužne iznijeti sve činjenice na kojima zasnivaju svoje zahtjeve i izvoditi dokaze kojima se utvrđuju te činjenice. Sud će razmotriti i utvrditi samo činjenice koje su stranke iznijele i odrediti izvođenje samo onih dokaza koje su stranke predložile, ako zakonom nije drugačije određeno. ${ }^{\text {" }} \mathrm{U}$ parničnom postupku $\mathrm{F} \mathrm{BiH}$ zastupljeno je raspravno načelo budući da stranke imaju ovlaštenje iznositi činjenice i predlagati dokaze za utvrđivanje tih činjenica. ${ }^{6}$ U Zakonu o parničnom postupku Federacije Bosne i Hercegovine (Službene novine Federacije BIH, broj 42/98) bilo je zastupljeno načelo materijalne istine po kojemu je sud utvrđivao pravno relevantne činjenice neovisno od prijedloga stranaka, sud je trebao po službenoj dužnosti prikupljati dokaze i potpuno i istinito utvrđivati sporne činjenice. Izmjenama u zakonu u smjeru oduzimanja sudu inkvizitornih ovlaštenja željelo se ubrzati parnični postupak na način da od aktivnosti stranaka ovisi odluka suda jer sud više nije u mogućnosti sam predlagati niti izvoditi dokaze. ${ }^{7}$ Stranke su dužne najkasnije na pripremnom

4 Triva, S., Dika, M., Građansko parnično procesno pravo, Narodne novine, Zagreb, 2004., str. 480 .

$5 \quad$ Čl. 7. st. 1. i 2. ZPP-a F BiH.

$6 \quad$ Određeno odstupanje od raspravnog načela je propisano čl. 7. st. 3. ZPP-a FBIH kojim je sud ovlašten utvrditi i činjenice koje stranke nisu iznijele i naložiti izvođenje dokaza koje stranke nisu predložile ako iz rezultata rasprave i dokazivanja proizlazi da stranke idu za tim da raspolažu zahtjevima kojima ne mogu raspolagati.

$7 \quad$ Iznimka od pravila da stranke izvode dokaze je uviđaj kojega izvodi sud te saslušanje stranke koja nema punomoćnika u postupku. 
ročištu iznijeti sve činjenice na kojima zasnivaju svoje zahtjeve i predložiti sve dokaze koje žele izvesti na glavnoj raspravi, te na pripremno ročište donijeti sve isprave i predmete koje žele upotrijebiti kao dokaz. ${ }^{8}$

Sud ovisno od rezultata raspravljanja na pripremnom ročištu donosi odluku o čemu će se raspravljati i koji će dokazi biti izvedeni na glavnoj raspravi. ${ }^{9}$ Time dolazimo do druge faze dokaznog postupka koja utječe na ekonomičnost i učinkovitost postupka. Sud treba odlučiti koje su činjenice pravno relevantne za rješavanje spora te koje je od ponuđenih dokaza potrebno izvesti u cilju utvrđivanja tih činjenica. Sud treba odbiti utvrđivanje činjenice koje nisu relevantne za spor među strankama ${ }^{10}$ te izvođenje dokaza koji nisu bitni za donošenje odluke. Od pripremljenosti i stručnosti suca ovisi hoće li se u postupku utvrđivati samo pravno relevantne činjenice ili će se postupak nepotrebno odugovlačiti zbog izvođenja nepotrebnih dokaza.

Dokaze izvode stranke na glavnoj raspravi. ${ }^{11}$ Način izvođenja ovisi od vrste dokaznog sredstva. ${ }^{12}$ Nakon iznošenja činjenica i izvođenja dokaza sud pristupa ocjeni dokaza i donošenju odluke. U našemu zakonodavstvu zastupljeno je načelo slobodne ocjene dokaza koje znači da sud nije vezan nikakvim pravilima u pogledu ocjene dokaza. To međutim ne treba shvatiti kao neograničenu slobodu jer je sud vezan pravilima iskustva i logike. Obrazloženje presude i žalba na presudu

8 Stranke mogu tijekom glavne rasprave iznositi nove činjenice i predlagati nove dokaze samo ako učine vjerojatnim da ih bez svoje krivnje nisu bili u mogućnosti iznijeti odnosno predložiti na pripremnom ročištu (čl. 102. st. 2. ZPP-a F BIH). Dakle, to pravo je priznato samo savjesnim strankama - stranke koje su za nove činjenice i dokaze saznale tek nakon održavanja pripremnog ročišta i zbog toga ih nije bila u mogućnosti navesti na pripremnom ročištu. Na taj način se utječe na ekonomičnost postupka i zabranu zloupotrebe procesnih ovlaštenja.

$9 \quad$ Čl. 81. ZPP-a F BiH.

10 Npr. u postupku zbog smetanja posjeda sud ne smije dopustiti izvođenje dokaza za utvrđivanjem prava vlasništva na nekretnini na kojoj se dogodilo smetanje.

11 Postoji nekoliko odstupanja od načela neposrednosti prilikom izvođenja dokaza. Sud može, na prijedlog stranke, odlučiti da se određeni dokazi izvedu pred zamoljenim sudom. U tom slučaju zapisnici o izvedenim dokazima pročitat će se na glavnoj raspravi (čl. 128. st.2. ZPP-a F BiH). Kada se osiguranje dokaza traži prije pokretanja postupka te u izuzetnim slučajevima ako je postupak u tijeku, nadležan je niži sud prvog stupnja na čijem se području nalaze stvari koje treba razgledati odnosno sud na čijem području boravi osoba koju treba saslušati (čl. 170. st. 2 ZPP-a F BiH). Iznimka od načela neposrednosti je predviđena i u slučaju održavanja ročišta pred novim sucem kada sud može odlučiti uz suglasnost stranaka da se ponovno ne saslušavaju svjedoci i vještaci i da se ne obavlja novi uviđaj već da se pročitaju zapisnici o izvođenju tih dokaza (čl. 114. st. 2. ZPP-a F BiH). 
također su elementi kojima se utječe na kontrolu slobodne ocjene dokaza. Sudac u obrazloženju presude treba navesti koje je činjenice utvrđivao, zašto i kako ih je utvrdio, ako su utvrđene dokazivanjem koji dokazi su izvedeni te kako ih je sud ocijenio.

Dokazivanje je dakle samo jedan od načina utvrđivanja činjenica, postoje činjenice koje se mogu utvrđivati i na drugi način.

\section{1. Činjenice koje se ne utvrđuju dokazivanjem}

U parničnom postupku postoje određene činjenice koje sud uzima kao dokazane bez provođenja postupka dokazivanja. To su priznate činjenice, općepoznate činjenice te pravne pretpostavke.

Činjenice priznate pred sudom se ne utvrđuju dokazivanjem, njih sud unosi u svoju odluku bez dokazivanja. Priznanje činjenica je jednostrana parnična radnja kojom stranka izjavljuje da su istiniti činjenični navodi na kojima parnični protivnik zasniva svoj zahtjev u parnici. ${ }^{13}$ Da bi se radilo o priznanju činjenica mora se raditi o priznanju činjenica koje su za stranku nepovoljne, dok bi priznanje činjenica koje su povoljne za stranku imalo značenje priznanja navoda koje se naknadno treba utvrditi dokazivanjem. Karakter priznanja ima samo priznanje koje je dano pred sudom, usmeno na ročištu ili pismeno van ročišta. Priznanje činjenica koje je dano izvan parnice na koju se odnosi nema procesni značaj priznanja te ga sud cijeni prema pravilima o ocjeni dokaza. Postoje određena odstupanja od pravila da se priznate činjenice ne dokazuju. Sud može narediti da se i priznate činjenice dokazuju ako smatra da stranke idu za tim da raspolažu zahtjevom kojim ne mogu raspolagati. ${ }^{14}$ Stranka može opozvati činjenice koje je priznala te će sud u tome slučaju, cijeneći sve okolnosti predmeta, ocijeniti hoće li činjenicu koju je stranka priznala pa opozvala uzeti kao priznatu ili osporenu. Priznanje činjenice treba razlikovati od priznanja tužbenog zahtjeva. Ako tuženi do zaključenja glavne rasprave prizna tužbeni zahtjev, sud će bez daljnjeg raspravljanja donijeti presudu kojom usvaja tužbeni zahtjev, odnosno donijet će presudu na temelju priznanja. ${ }^{15}$ Izjava tuženika da je tužbeni zahtjev osnovan je izjava volje, a ne izjava o znanju, to je materijalna dispozicija tuženika. S obzirom da je to jednostrana parnična radnja njegova vrijednost ne zavisi od volje ili ak-

\footnotetext{
13 Triva, S., Dika, M., op. cit. , str. 488.

14 Čalija, B., Omanović, S., Građansko procesno pravo, Univerzitet u Sarajevu Pravni fakultet, Sarajevo, 2000., str. 216.

15 Čl. 180. st. 1. ZPP-a F BiH.
} 
tivnosti suprotne stranke, dovoljna je jasna, izričita i bezuvjetna izjava tuženika. ${ }^{16}$ Iako postoje i druga mišljenja te se izjava o priznanju smatra izjavom o znanju ${ }^{17}$ po zakonodavstvu F BiH izjava o priznanju se može smatrati izjavom volje kojom stranka raspolaže svojim dispozitivnim ovlaštenjima. Ako sud utvrdi da stranka raspolaže zahtjevima kojima ne može raspolagati sud će narediti da se i priznate činjenice dokazuju dok u ostalim slučajevima sud ne može narediti izvođenje dokaza.

Općepoznate činjenice su takve činjenice koje su poznate širem krugu ljudi (ne moraju biti poznate svima) u sredini u kojoj se suđenje obavlja. ${ }^{18} \mathrm{ZPP}-\mathrm{om} \mathrm{F} \mathrm{BiH}$ je propisano da ne treba dokazivati činjenice koje su općepoznate. ${ }^{19}$ Takve činjenice sud uzima kao u obzir prilikom donošenja odluke. Opseg notornosti jedne činjenice, odnosno bila ona šira ili uža, nema utjecaja na pravilo da takve činjenice ne podliježu dokazivanju. Razlike se ogledaju samo u tome što sud činjenicu šire notornosti unosi u svoju odluku bez dodatnih objašnjenja, dok kod činjenice uže notornosti sud je dužan navesti da su takve činjenice poznate na području suda na kome se suđenje obavlja. ${ }^{20}$ Kako je u našem parničnom postupku zastupljeno raspravno načelo sud bi trebao obavijestiti stranke o činjenicama koje sud smatra notornim i omogućiti im da o njima iznesu svoje stajalište jer je dopušteno dokazivati da neka činjenica nije notorna ili da ne postoji. Iako u zakonu nije precizno navedeno i iako je napušteno načelo materijalne istine, sud je dužan po službenoj dužnosti uzimati općepoznate činjenice u osnov svoje odluke. ${ }^{21}$

Zakonske presumpcije (praesumptiones juris) pravna su pravila o zaključivanju o postojanju određenih pravno relevantnih činjenica na temelju utvrđenja da postoje određene činjenice koje nisu neposredno pravno relevantne, ali su s njima u određenoj uzročnoj vezi. ${ }^{22} \mathrm{ZPP}-\mathrm{om} \mathrm{FBiH}$ je određeno da činjenice čije postojanje zakon pretpostavlja ne treba dokazivati, ali se može dokazivati da te činjenice ne

16 Čizmić, J., Komentar zakona o parničnom postupku Federacije Bosne i Hercegovine, Privredna štampa, Sarajevo, 2009., str. 390.

17 Opširnije o tome Triva, S., Dika, M., op. cit, str. 492.

18 Triva, S., Dika, M., op. cit., str. 487.

19 Čl. 125. st. 4. ZPP-a F BiH.

Čalija, B., Omanović, S., op. cit., str. 216. - 217.

21 Na takav zaključak upućuju odredbe ZPP-a F BiH. Tako je u čl. 182. st. 2. točka 2. propisano da sud neće donijeti presudu zbog propuštanja ako su činjenice na kojima se temelji tužbeni zahtjev u očiglednoj protivnosti s dokazima koje je sam tužitelj predložio ili s činjenicama koje su općepoznate. U čl. 332. st. 2. određeno je da će sud, vezano za prijedlog za povrat u prijašnje stanje, zakazati ročište, osim ako su činjenice na kojima se prijedlog zasniva općepoznate.

22 Triva, S., Dika, M., op. cit., str. 486. 
postoje, ako zakonom nije što drugo određeno. ${ }^{23}$ Prilikom utvrđivanja činjenica primjenom pravnih presumpcija stranka koja se poziva na tu presumpciju dužna je dokazati postojanje presumptivne baze. Dakle, umjesto da dokazuje neposredno relevantnu činjenicu stranka dokazuje posredno relevantnu činjenicu, koju je lakše dokazati. Postoje dvije vrste pravnih pretpostavki, oborive i neoborive. Neoborive pravne pretpostavke (praesumptio juris et de jure) su pravila materijalnog prava koja su pravno uobličena u formi pravne pretpostavke. ${ }^{24}$ Kod takvih pretpostavki zakon ne dopušta dokazivanje da ne postoje činjenice koje zakon pretpostavlja. Oborive presumpcije (praesumptiones juris tantum) takve su presumpcije kod kojih je dopušten dokaz o protivnom. Teret dokazivanja se u tome slučaju prebacuje na suprotnu stranku od one koja se poziva na te činjenice. Protivnik stranke koja se poziva na zakonske presumpcije, bilo oborive ili neoborive, uvijek ima mogućnost osporavati postojanje tako utvrđene činjenice tako što će osporavati postojanje činjenice koja predstavlja bazu za primjenu pravila o zakonskoj presumpciji. ${ }^{25}$

\section{Elektronički dokazi}

Sud slobodnom ocjenom dokaza utvrđuje činjenice na osnovu kojih donosi odluku. ZPP-om FBiH su kao dokazna sredstva predviđeni uviđaj, isprave, svjedoci, vještaci i saslušanje stranaka te su propisana pravila za postupanje suda i stranaka prilikom izvođenja dokaza. Bez obzira na navedena dokazna sredstva pravno relevantne činjenice mogu se utvrđivati svim mogućim sredstvima obavještavanja koja su pribavljena na zakonit način. Razvojem tehnologije i njezinom upotrebom u svakodnevnoj komunikaciji dolazi do pojave elektroničkih zapisa o tim aktivnostima koji mogu poslužiti kao dokaz o određenim činjenicama. To dolazimo do pojma elektroničkog dokaza. Zakonom o parničnom postupku nije definiran pojam dokaza, pa tako ni elektroničkog dokaza. Elektronički dokaz je svaki elektronički zapis koji je nastao na računalu ili sličnom uređaju, od strane čovjeka ili je automatski generiran, a koji može služiti kao dokaz pred sudom ili drugim državnim organima. ${ }^{26}$ Elektronički dokaz je elektronički pohranjena informacija na bilo kojem računalnom uređaju koja može poslužiti kao dokaz u

\footnotetext{
$23 \quad$ Čl. 125. st. 3. ZPP-a F BiH

24 Čalija, B., Omanović, S., op. cit., str. 217.

25 Triva, S., Dika, M., op. cit., str. 487.

26 Scientific Working Group on Digital Evidence (SWGDE), „Digital Evidence: Standards and Principles“, u: Forensic Science Communications, Vol. 2, 2/2000, str.1.
} 
sudskom postupku. ${ }^{27}$ Elektronički dokaz su podaci koju su korišteni, pohranjeni ili preneseni pomoću bilo kojega uređaja kojega je čovjek napravio, računala ili računalnog sustava ili koji su preneseni komunikacijskim sustavom, koji mogu utjecati na vjerojatnost činjenica koje stranke navode. ${ }^{28}$ Elektronički dokazi prolaze kroz dvije faze, fazu provjere autentičnosti i fazu ocjene od strane suda. Sud najčešće nije u mogućnosti sam utvrditi vjerodostojnost takvih dokaza bez stručne pomoći, vještaka informatičke ili druge odgovarajuće struke. Kako ne postoje posebne procesne odredbe za elektroničke dokaze prilikom njihovog izvođenja i ocjenjivanja primjenjuju se odredbe zakona o parničnom postupku. Na taj način, primjenom odredbi zakona o parničnom postupku, svaka stranka je dužna dokazati autentičnost dokaza koje je predložila nakon čega će sud odlučiti koji će se dokazi izvesti u cilju utvrđivanja autentičnosti elektroničkih dokaza.

Vezano za temu elektroničkih dokaza nužno je analizirati odredbe zakona o elektroničkom dokumentu i elektroničkom potpisu kojima je regulirana pravna valjanost elektroničkog dokumenta koji se koristi u postupcima koji se vode pred nadležnim tijelima te njihova pravna valjanost.

\section{Vještačenje elektroničkih dokaza}

Vještak je stručna osoba koja se pojavljuje u funkciji dokaznog sredstva kada je u sporu za utvrđivanje određenih činjenica stručno znanje kojim sud ne raspolaže. Činjenica da se vještačenje provodi samo kada sud ne raspolaže određenim stručnim znanjem čini ovo dokazno sredstvo specifičnim i složenim izvorom saznanja. ${ }^{29}$ Stranka koja predlaže provođenja dokaza vještačenjem dužna je predložiti i osobu koja će obaviti vještačenje, kao i predmet i obujam vještačenja. Suprotna stranka ima mogućnost izjasniti se o predloženom vještaku i predmetu i obujmu vještačenja. Ako stranke ne postignu sporazum o tome, odluku o vještaku i predmetu i obujmu vještačenja treba donijeti sud. ${ }^{30}$ Smatramo da bi u tome slučaju sud trebao za vještaka odrediti treću osobu s liste sudskih vještaka koju nije predložila ni jedna od stranaka. Bilo kakvo drugačije postupanje suda može dovesti u pitanje njegovu nepristranost. Cilj dokazivanja je utvrđivanje spornih

\footnotetext{
27 Volonino, Linda, „Electronic Evidence and Computer Forensics“, Communications of the Association for Information Systems: Vol. 12 , article 27, 2003., str. 459. (dostupno na http:// aisel.aisnet.org/cais/vol12/iss1/27) Mason, S., Electronic Evidence, 3rd edn, LexisNexis Butterworths, London, 2012., str. 27.

29 Čalija, B., Omanović, S., op. cit., str. 226.

30 Čl. 148. ZPP-a F BiH.
} 
činjenica, a izvođenje dokaza vještačenjem određuje se u situacijama kada je radi utvrđenja ili razjašnjenja određene činjenice potrebno stručno znanje kojim sud ne raspolaže. Sud nije vezan nalazom i mišljenjem vještaka jer sud nalaz i mišljenje vještaka, kao i sve druge dokaze, cijeni slobodnom ocjenom. Ako sud prihvati nalaz i mišljenje vještaka bez kritičke analize s ostalim dokazima, te pravilima logičkog i razumnog razmišljanja i zaključivanja, sud vještaku prepušta ulogu suca, a to je neprihvatljivo. ${ }^{31}$ Treba imati na umu da je vještačenje samo jedno dokazno sredstvo, te sud treba cijeniti i druge dokaze koji su provedeni u postupku. ${ }^{32}$ Vještak uvijek mora svoje mišljenje obrazložiti. ${ }^{33}$ Obrazloženje bi trebalo biti takvo da ga sud i stranke mogu razumjeti. Ako obrazloženje sadrži pretjeran znanstveni pristup te ako je napisano jezikom koji ne mogu razumjeti osobe koje nemaju dovoljno stručnog znanja iz određenog područja, to predstavlja problem prilikom ocjene toga dokaza. Dokaz vještačenjem određuje se i zbog toga jer sud nema stručno znanje o činjenici koju treba utvrditi ili razjasniti te ako sud ne može razumjeti nalaz vještaka, onda ne može ni pravilno odlučiti o ocjeni toga dokaza.

Postoji cijeli niz elektroničkih dokaza koji nas okružuju u svakodnevnom životu, a kojih nismo ni svjesni. Elektronički dokazi predstavljaju kombinaciju različitih informacija (tekst, slika, audio snimka i sl.). ${ }^{34}$ Elektronički dokazi mogu biti u različitim oblicima, taj pojam može obuhvaćati fotografije, filmove, diskove, računalne baze podataka, magnetofonske vrpce i sl. ${ }^{35}$ Vještačenje takvih dokaza je u domeni vještaka informatičke, elektroničke ili komunikacijske struke. Neke od prednosti elektroničkih dokaza su da se oni teško mogu uništiti jer se mogu povratiti i situacijama kada su izbrisani, uz odgovarajuće znanje i alate može se utvrditi njihova autentičnost, pošiljatelj, vrijeme slanja, jesu li mijenjani i sl. S obzirom da za elektroničke dokaze ne postoje posebna pravila prilikom njihovog

31 „Dakle, sud nalaz i mišljenje vještaka koristi samo radi razjašnjenja ili utvrđivanja onih činjenica za koje je potrebno stručno znanje kojim sud ne raspolaže." Odluka Vrhovnog suda Srbije GŽ-3174/77.

32 „Činjenica što je u parnici izostalo dokazivanje očinstva metodom genetske daktiloskopije (ispitivanje strukture i svojstva DNK), sama za sebe, ne znači da su pouzdanost drugih dokaza $\mathrm{i}$ istinitost činjenica na kojima je zasnovana presuda sumnjivi, odnosno da ovi dokazi nemaju vrijednost." Odluka Vrhovnog suda Republike Srpske broj Rev-302/01 od 19.04.2002.godine.

33 Čl. 154. st.2. ZPP-a F BiH.

34 Protrka, N., „Računalni podaci kao elektronički (digitalni) dokazi“, u: Policija i sigurnost, godina 20, broj 1, 2011., str. 2.

35 Čizmić, J., Boban, M., „Elektronički dokazi u sudskom postupku i računalna forenzička analiza“, u: Zbornik Pravnog fakulteta Sveučilišta u Rijeci, v. 38, br. 1, 23. - 50., 2017., str. 38. 
izvođenja i ocjenjivanja primjenjuju se pravila zakona o parničnom postupku. Dakle, ako jedna stranka predloži da se takav dokaz izvede u postupku, ukoliko sud nije u mogućnosti sam utvrditi autentičnost toga dokaza, morat će predložiti vještačenje da bi se mogla utvrditi autentičnost toga dokaza. ${ }^{36}$ Kao što smo već rekli, ocjenjivanje takvih dokaza odvija se kroz dvije faze, fazu ocjene autentičnosti i ocjena od strane suda. Podatak o tomu kako su dokazi pribavljeni, čuvani, preneseni, zaštićeni od izmjena i kako se s njima manipuliralo je presudan za donošenje odluke o njihovom prihvaćanju na sudu. ${ }^{37}$ Elektronički dokazi su osjetljivi, lako se brišu i mijenjaju, a time i kompromitiraju. Specijalni forenzični alati omogućavaju povrat i analizu i obrisanih, skrivenih ili privremenih datoteka koje nisu vidljive u svakodnevnom normalnom radu. ${ }^{38}$

\section{Elektronički dokumenti}

Na području Bosne i Hercegovine doneseni su Zakon o elektroničkom dokumentu BiH (Sl. glasnik BiH, 58/14), Zakon o elektroničkom dokumentu Federacije $\mathrm{BiH}$ (Sl. novine, broj 55/13), Zakon o elektroničkom dokumentu Republike Srpske (Sl. Glasnik Republike Srpske, 106/15), Zakon o elektroničkom potpisu $\mathrm{BiH}$ (Sl. glasnik $\mathrm{BiH}, 91 / 06)$ te Zakon o elektroničkom potpisu Republike Srpske (Službeni glasnik Republike Srpske, br. 106/15). Značaj zakona o elektroničkom dokumentu ogleda se u potrebi stvaranja uvjeta za izjednačavanje elektroničkog oblika dokumenta s pisanim oblikom, te u odvijanju pravnog prometa između fizičkih i pravnih osoba, kao i između tih osoba i organa javne vlasti kao i organa javne vlasti međusobno. Elektronički dokument je logički i funkcionalno povezan skup podataka koji su elektronički kreirani, poslani, primljeni ili pohranjeni na elektroničkom, magnetnom, optičkom ili drugom mediju i koji sadrži svojstva pomoću kojih se identificira izvor, utvrđuje vjerodostojnost sadržaja i dokazuje postojanost sadržaja u vremenu, a uključuje sve oblike pisanog teksta, podatke, slike, crteže, karte, zvuk, glazbu, govor i sl. ${ }^{39} \mathrm{U}$ ovome ćemo radu analizirati

$36 \quad$ S obzirom da se radi o dokazima koji će se u budućnosti primjenjivati u sve većem broju postoje mišljenja da bi se na pravne fakultete trebala uvesti edukacija o elektroničkim dokazima. Bitno je poznavati i osnove tehnologije i načine kako sigurno rukovati s takvim dokazima u cilju njihovog prihvaćanja na sudu. Opširnije u: Wong, Denis Huiwen, „Educating for the Future: Teaching Evidence in the Technological Age", Digital Evidence and Electronic Signature Law Review, 10, 16. - 22., 2013.

37 Protrka, N., op. cit., str. 45.

$38 \quad$ Ibid., str. 2.

39 Čl. 4. točka 1. Zakona o elektroničkom dokumentu BIH (Službeni glasnik BIH, broj 58/14). 
odredbe Zakona o elektroničkom dokumentu $\mathrm{BiH}$ (Sl. glasnik BiH, 58/14, dalje u tekstu ZED) i Zakona o elektroničkom potpisu BiH (Sl. glasnik BiH, 91/06, dalje u tekstu ZEP) ${ }^{40}$, s obzirom da su i entitetski zakoni na jednak način uredili pitanje korištenja elektroničkih dokumenata kao dokaza. Navedene zakone analizirat ćemo u pogledu primjene elektroničkog dokumenta kao dokaza u sudskom postupku i njegovu pravnu valjanost, te pravno djelovanje elektroničkog potpisa.

Zakonom su propisana pravna snaga elektroničkog dokumenta i koji uvjeti trebaju biti ispunjeni da bi elektronički dokument imao istu pravnu valjanost kao i dokument na papiru. ${ }^{41}$ Elektronički dokument koji nosi napredni elektronički potpis ili napredni elektronički vremenski pečat nadležnog tijela, fizičke ili pravne osobe koja je nadležna za izdavanje relevantnog dokumenta ima pravnu presumpciju vjerodostojnosti i cjelovitosti, pod uvjetom da dokument ne sadrži nikakve dinamičke karakteristike koje automatski mogu izmijeniti dokument. ${ }^{42}$ Za elektronički dokument je važno pitanje originalnosti koje je riješeno u čl. 9. ZED-a. ${ }^{43}$ Preslika elektroničkog dokumenta izrađuje se ovjerom ispisa elektroničkog dokumenta na papiru. ${ }^{4}$ Čl. 11 . ZED-a propisano je da preslika dokumenta koja je izrađena u skladu sa zakonom ima istu pravnu snagu i može se koristiti ravnopravno u svim radnjama za koje je takav dokument potreban. Zakonom je definirana upotreba elektroničkog dokumenta kao dokaznog sredstva. Elektronički dokument koji je izrađen u skladu s odredbama zakona prihvaća se kao dokaz u postupcima koja se vode pred nadležnim tijelima. Pri ocjeni ispravnosti elektroničkog dokumenta moraju se uzeti u obzir pojedinosti o njegovoj izradi, skladištenju, prijenosu, čuvanju, vjerodostojnosti i nepromjenjivosti. ${ }^{45} \mathrm{Za}$ očekivati je da će se u budućnosti povećati broj elektroničkih dokumenata koji će biti upotrijebljeni kao dokaz u parničnom postupku. S obzirom da ZPP-om F $\mathrm{BiH}$ sud nije ograničen u izboru dokaznih sredstava mišljenja smo da ne postoji

$40 \quad$ Iako je zakon o elektroničkom potpisu $\mathrm{BiH}$ usvojen još 2006.godine, tek je 15. siječnja 2018. godine s radom počeo Ured za nadzor i akreditaciju ovjeritelja, čime su se stekli uvjeti za primjenu zakona o elektronskom potpisu. U nadležnosti je ureda registriranje ovjeritelja koji podnesu obavijest o početku rada i akreditiranje ovjeritelja u skladu sa Zakonom o elektroničkom potpisu.

Čl. 5. st. 2. ZED-a.

„Svaki pojedinačni primjerak elektroničkog dokumenta koji je potpisan naprednim elektroničkim potpisom smatra se izvornikom. Ako ista osoba izradi dva i više dokumenata istog sadržaja, od kojih je jedan primjerak u elektroničkom obliku, a drugi tiskan na papiru, ti se dokumenti smatraju neovisnim. U tome slučaju dokument na papiru se ne smatra preslikom elektroničkog dokumenta“.
Čl. 10. ZED-a.

Čl. 12. ZED-a. 
prepreka upotrebe elektroničkih dokumenata definiranih ZED-om kao dokaza u postupku. U prilog tome ide i odredba ZED-a kojom je izričito određeno da se ne može odbiti elektronički dokument kao dokaz samo iz razloga jer se radi o takvoj vrsti dokumenta. Ocjena takvih dokumenata od strane suda ovisit će od tehničke opremljenosti i stručnosti sudaca. Potrebno je provesti određene edukacije u smjeru osposobljavanja sudaca o načinu utvrđivanja vjerodostojnosti elektroničkih dokumenata koji nose presumpciju vjerodostojnosti i cjelovitosti.

ZEP-om je regulirano opće pravo djelovanje elektroničkog potpisa na način da se u pravnom i poslovnom prometu mogu koristiti elektronski potpisi ${ }^{46}$ formirani postupcima različitih razina sigurnosti i zasnovani na potvrdama različitih klasa. Pravno djelovanje elektroničkog potpisa i njegova upotreba kao dokaznog sredstva ne može se isključiti zbog činjenice da je elektronički potpis dostupan jedino u elektroničkoj formi ili zbog toga što nije zasnovan na kvalificiranoj potvrdi, ili kvalificiranoj potvrdi akreditiranog ovjeritelja, ili zbog toga što nije formiran upotrebom tehničkih sredstva i postupaka iz ZEP-a. ${ }^{47} \mathrm{Za}$ ocjenu dokazne snage takvih potpisa, odnosno utvrđivanje njihove autentičnosti bit će potrebno sudjelovanje vještaka određene struke. Ako se na takav način i utvrdi autentičnost potpisa sud će slobodnom ocjenom pristupiti ocjeni istinitosti sadržaja toga dokumenta. Čl. 5. istog zakona određeno je da siguran elektronski potpis zadovoljava pravne zahtjeve za vlastoručan potpis i osobito pisanu formu, ako posebnim zakonom ili sporazumom stranaka nije drugačije određeno (npr. siguran elektronski potpis neće imati pravno djelovanje pisane forme kod pravnih poslova iz obiteljskog ili nasljednog prava koji zahtijevaju pisanu formu).

Prilikom ocjene ovakvih dokaza sud mora voditi računa o više okolnosti. Ako se radi o elektroničkim dokumentima koje izdaju ovlaštene pravne osobe i osobe $s$ javnim ovlastima u okviru svoje nadležnosti i u skladu sa svim elementima propisanim ZED-om i ZEP-om, takve isprave bi sud trebao cijeniti kao javne isprave. Ako se radi o elektroničkim dokumentima koje izdaju pravne osobe ili fizičke osobe bez javnih ovlasti, u takvom bi slučaju sud trebao provesti vještačenje da bi se utvrdila autentičnost navedene isprave, kao i drugi podaci koje je moguće

„Elektronički potpis su podaci u elektroničkom obliku koji prate druge podatke u elektroničkom obliku ili su s njima logički povezani i omogućavaju utvrđivanje identiteta potpisnika. Siguran elektronički potpis je elektronički potpis koji je:1) dodijeljen isključivo potpisniku, 2) omogućava identificiranje potpisnika, 3) formiran upotrebom sredstava koja su u potpunosti pod kontrolom potpisnika, 4) povezan s podacima na koje se odnosi tako da se može utvrditi svaka naknadna promjena tih podataka, 5) zasnovan na kvalificiranoj potvrdi i formiran upotrebom tehničkih sredstava i postupaka koji su u skladu sa sigurnosnim zahtjevima ovog Zakona i na osnovu njega donesenih podzakonskih propisa." Čl. 3.st. 1. točka 1. i 3. 
ŠOLJIĆ, A., Elektronički dokazi u parničnom postupku Bosne i Hercegovine Zbornik radova Pravnog fakulteta Sveučilišta u Mostaru, br. XXVII., 2019., str. 121. - 137.

utvrditi (vrijeme stvaranja, identitet stvaratelja, itd.), a u cilju dokazivanja vjerodostojnosti takvog dokumenta. ${ }^{48}$

\section{Komunikacija suda sa strankama elektroničkim putem}

Razvojem tehnologije dolazi i do promjena u načinu rada na sudovima. Visoko sudsko i tužiteljsko vijeće $\mathrm{BiH}^{49}$ je 2004. godine usvajanjem Strategije informatizacije pravosuđa $\mathrm{BiH}$ započeo proces mijenjanja načina funkcioniranja pravosudnih institucija koji se nije značajnije mijenjao od početka 20. stoljeća. Razlog za provođenjem informatizacije pravosuđa je povećanje transparentnosti rada sudova u $\mathrm{BiH}$ i tužiteljstva, te pravovremeno i učinkovito pružanje kvalitetnih usluga.

Informatizacija pravosuđa u $\mathrm{BiH}$ odvijala se kroz dvije faze. Prva faza je trajala od sredine 2004. godine do kraja 2010. godine. Najznačajnija dostignuća u tome razdoblju su uspostavljanje centraliziranog operativnog okruženja za obradu i pohranu podataka u VSTV-u, uspostavljanje državne mreže širokog područja (WAN) koja povezuje 93 institucije, uspostavljanje lokalne mreža u 93 institucije, pravosudne institucije su opskrbljene sa preko 150 servera, osigurana su računala za gotovo 5.000 korisnika u pravosuđu, razvijen je i implementiran sustav za upravljanje sudskim predmetima - CMS, a za potrebe tužiteljstva razvijen je sustav za upravljanje tužilačkim predmetima - TCMS, građanima je omogućen lakši pristup informacijama putem pravosudnog web-portala, uspostavljen je sustav centralizirane, regionalne i lokalne IKT podrške, više od 120 IKT stručnjaka zaposleno je u sudovima i tužiteljstvima širom $\mathrm{BiH}$, postavljeno je 50 info-pultova u javnim prostorima sudova širom $\mathrm{BiH}$, kako bi se unaprijedila online dostu-

48 Opširnije Lisičar, H., „Mogućnost uporabe elektroničke isprave i elektroničkih dokumenata u parničnom postupku“, Zbornik Pravnog fakulteta Zagreb, vol. 60, (3), 2010., str. 1416. - 1418.

49 Visoko sudsko i tužiteljsko Vijeće BiH (VSTV BiH) je nezavisni organ koji je osnovan Zakonom o Visokom sudskom i tužiteljskom vijeću (Službeni glasnik BiH, broj: 25/04, Zakon o VSTV-u BiH). Zakon je stupio na snagu 1. 6. 2004.godine. U čl. 1. navedeno je da se tim zakonom regulira i njegov rad, organizacija, nadležnosti, ovlaštenja, uvjeti i mandat za vršenje sudačke i tužilačke funkcije, imenovanje sudaca i tužitelja, disciplinska odgovornost sudaca i tužitelja, privremeno udaljenje sudaca i tužitelja od vršenja dužnosti, nespojivost dužnosti sudaca i tužitelja s drugim funkcijama, prestanak mandata sudaca i tužitelja i druga pitanja u vezi s radom VSTV-a. Nadležnosti VSTV-a su definiranje čl. 17. Zakona o VSTV-U BiH. Između ostalog VSTV ima nadležnost za imenovanje nositelja pravosudnih funkcija na svim razinama u $\mathrm{BiH}$, disciplinsku odgovornost nositelja pravosudnih funkcija, stručno usavršavanje sudaca i tužitelja, pravosudnu upravu i nadzor. 
pnost informacija o sudovima svim građanima, uključujući i one koji nisu u mogućnosti pristupiti informacijama putem interneta s drugih lokacija. U drugoj fazi, početkom 2014. godine, započeo je proces razvoja nove verzije najvažnijeg segmenta pravosudnog informacijskog sustava - Sustava za upravljanje predmetima u sudovima i tužilaštvima (CMS). ${ }^{50}$

CMS sustav omogućava strankama u postupku da odmah dobiju informaciju o broju predmeta i sucu kojem je predmet dodijeljen u rad. Otklanjanjem ljudskog faktora iz procesa dodjeljivanja predmeta u rad sucu, zagarantirana je nepristranost u ovom dijelu procesa, s obzirom da sustav dodjeljuje predmete sucima po osnovu specijalizacija u pravnim oblastima po principu ujednačene slučajne dodjele. ${ }^{51} \mathrm{U}$ skladu s čl. 10. i 11. Pravilnika podaci se evidentiraju u elektronskoj formi i čuvaju na elektronskom mediju za pohranu podataka. Svi dokumenti i prilozi evidentiraju se elektronski i skeniraju. Pravilnikom je u čl. 117. određeno da modul za pristup predmetima putem interneta omogućava strankama, zakonskim zastupnicima i punomoćnicima, a po odluci suda i drugim sudionicima u postupku, autorizirani pristup podacima evidentiranim u CMS, korištenjem broja predmeta i jedinstvenog pristupnog kôda, odnosno korištenjem korisničkog računa. Jedinstveni pristupni kôd se izdaje se za sve vrste predmeta osim za predmete kaznenog referata. $\mathrm{Na}$ ovaj način se u $\mathrm{BiH}$ znatno utjecalo na transparentnost postupka pred sudom. Stranke korištenjem jedinstvenog pristupnog kôda uvijek mogu pristupiti predmetu putem interneta i izvršiti uvid u postupanje suda i sve podneske koje su dostavile stranke i ostali sudionici u postupku. U određenim predmetima komunikacija suda elektroničkim putem sa strankama je proširena ${ }^{52}$, odnosno omogućeno je podnošenje podnesaka elektroničkim putem.

50 Podatak preuzet s https://vsts.pravosudje.ba/vstv/faces/kategorijevijesti.jsp?ins=141\&modul=1203\&kolona=12101 (21.9.2018.godine).

51 Čl. 8. Pravilnika o sustavu za automatsko upravljanje predmetima u sudovima (CMS) (Službeni glasnik BiH, broj 04/16, dalje u tekstu Pravilnik.)

2012. godine VSTV BiH donijelo je odluku o primjeni sustava za elektroničko podnošenje i obradu predmeta male vrijednosti (SOKOP Mal) u prvostupanjskim sudovima u $\mathrm{BiH}$. Sustav SOKOP Mal primjenjuje se u sudovima koji upute dopis VSTV-u BiH. U skladu s Naputkom za postupanje putem sustava za elektroničko podnošenje i obradu predmeta male vrijednosti/tzv. „komunalnih“ predmeta (SOKOP Mal sustav), koji je VSTV donijelo na sjednici održanoj 11. i 12. srpnja 2012.godine, predmeti u kojima je omogućeno elektroničko slanje podnesaka sudu i elektronička obrada predmeta su parnični predmeti u kojima se tužbeni zahtjev odnosi na potraživanje u novcu koje ne prelazi iznos od $5.000 \mathrm{KM}$ i za koje se kao dokaz može koristiti, pored eventualnih drugih dokaza, izvod iz knjigovodstvene evidencije; ovršni predmeti koji se mogu inicirati prijedlogom za ovrhu na osnovu vjerodostojne isprave i ovršni predmeti koji se mogu inicirati ili nastaviti na osnovu pravosnažne presude. Naputkom je reguliran elektronički prijem podnesaka vanjskih korisnika, elektronička dostava vanjskim korisnicima, prijem podnesaka i dostava strankama koji nisu korisnici elektroničkog sustava. Ukoliko se u predmetu dostavljenom 
Ovakvim načinom rada ne utječe se samo na transparentnost nego i na ekonomičnost. Sucima je omogućeno jednostavnije obavljanje pojedinih radnji vezanih za predmet te im na taj način ostaje više vremena za proučavanje predmeta. Omogućena je lakša kontrola rada sudova, lakše se mogu sačinjavati izvještaji o predmetima prema raznim kriterijima. Tehnologiju treba koristiti da se svim sudionicima olakša postupak na način da se strankama osigura jednostavniji pristup sudu, a sudu omogući jednostavnije obavljanje tehničkih radnji vezanih za predmet.

\section{Zaključak}

Način poslovanja i komuniciranja se promijenio. Dolazi do pojave elektroničkih dokaza koji predstavljaju važan izvor informacija o činjenicama koje mogu biti predmet spora među strankama. Prilikom izvođenja takvih dokaza u parničnom postupku primjenjuju se odredbe o dokazivanju koje su propisane zakonom o parničnom postupku. Prema tim odredbama, svaka stranka je dužna dokazati činjenice na kojima temelji svoj zahtjev. Iako ne postoje posebna pravila za elektroničke dokaze mišljenja smo da su stranke dužne prikupiti i prezentirati te dokaze na način koji neće ugroziti integritet i autentičnost dokaza. Suprotnim postupanjem takav dokaz neće pružati dovoljno osnova za utvrđivanje postojanja odnosno nepostojanja neke činjenice. Pitanje autentičnosti je jako bitno kod elektroničkih dokaza. S obzirom na promjenjivost takvih dokaza od velikog je značaja način na koji su se ti dokazi prikupili. Stranke bi trebale predložiti da se provede vještačenje kojim bi se moglo utvrditi autentičnost takvih dokaza. Ako stranke ne predlože vještačenje, sud će takve dokaze cijeniti slobodnom ocjenom u skladu s odredbama zakona. Da bi sud mogao pristupiti kritičkoj analizi nalaza i mišljenja koji se odnose na takve dokaze, a i općenito da bi ocijenio dokaznu vrijednost elektroničkih dokaza, nužno je provesti određene edukacije da bi se suci upoznali s osnovama vezanim za razvoj tehnologije. Sud nije vezan ni

putem SOKOP sustava ispune pretpostavke za otvaranje rasprave, sustav omogućava elektronski prijenos podataka u CMS sustavu gdje se nastavlja redovni parnični postupak. Također, ukoliko po završetku parničnog postupka dođe do potrebe za ovrhom, sustav omogućava da se postupak ovrhe provede u SOKOP Mal sustavu, putem elektronske razmjene podataka između dva sustava. Sustav omogućava svojim vanjskim korisnicima uvid $\mathrm{u}$ sve svoje predmete te preuzimanje podataka u odgovarajućem formatu odnosno putem web-servisa. Tehničke pretpostavke za korištenje sustava su: kvalificirana elektronička potvrda čija je validnost priznata u BiH u skladu sa članom 24. stavka 1. ZEP-a BiH i internet konekcija (preporučena je minimalna brzina od $1 \mathrm{Mbps}$ ). Trenutno se ovaj sustav primjenjuje na 16 prvostupanjskih sudova u $\mathrm{BiH}$. 
nalazom ni mišljenjem vještaka te ne smije prihvatiti mišljenje vještaka bez kritičke analize zasnovane na pravilima logičkog zaključivanja i iskustva. Uspješno obavljanje vještačenja zahtijeva suradnju suda i vještaka. Sud treba u skladu s prijedlozima stranaka vještaka detaljno uputiti o čemu treba vještačiti te obujmu vještačenja. Vještak treba u svom nalazu i mišljenju jasno navesti koje je metode koristio i koja je pravila struke primijenio, te koji je zaključak na osnovu takvog postupka donio. Nedostatak stručnog znanja ne može biti razlog da sud ne može cijeniti mišljenje vještaka i njegovu dokaznu vrijednost. Prilikom izvođenja dokaza vještačenjem i stranke mogu nalaz i mišljenje vještaka podvrgnuti diskusiji i kritici na raspravi postavljanjem pitanja vještaku u vezi s vještačenjem.

Sudovi su također prilagodili svoj način rada u skladu s nastalim promjenama, što je još jedan od pokazatelja da su tehnologija i elektronički način komuniciranja neizostavna pojava današnjeg svijeta. Stvaranjem zakonskog okvira i uvođenjem modernih informacijskih tehnologija utječe se na ekonomičnost $\mathrm{i}$ učinkovitost $\mathrm{u}$ postupanju između građana i institucija. Uz sve pozitivne učinke koje tehnologija nosi treba biti oprezan s obzirom na vrstu posla koja se obavlja na sudu, te je prvenstveno potrebno osigurati sigurnost u takvom načinu rada. 


\section{ELECTRONIC EVIDENCE IN CIVIL PROCEEDINGS IN BOSNIA AND HERZEGOVINA}

Summary: Process of proving is the central part of civil litigation whose purpose is to establish the facts that are essential for decision-making. This procedure takes place in a manner prescribed by law. According to the civil law procedure of Bosnia and Herzegovina, the initiative for offering evidence is in the hands of the parties. The court is only exceptionally empowered to deal with facts which the parties have not put forward and produce evidence which the parties have not proposed. Regardless of the means of evidence that are prescribed by law, legally relevant facts can be determined by all means of notification that are obtained legally. In this paper, the author will present general provisions on evidence, while the second part of the paper will consider electronic evidence.

Technology development has an impact on all spheres of society, also including the judicial proceedings. Communication and business are increasingly being done electronically. Thus, various data can be stored that can serve as evidence in court proceedings. This paper explains what electronic evidence is and how it can be used in the civil litigation of Bosnia and Herzegovina. Although judges are not bound by legal rules regarding the evaluation of evidence, regarding certain type of electronic evidence there are legal presumptions that affect the legal value of such documents.

Keywords: proving, electronic evidence, electronic document, expertise, computerization 